\title{
RUMINAL AND BLOOD CHARACTERISTICS OF NUBIAN GOATS DOSED WITH THE GROWTH PROMOTER MONENSIN
}

\author{
H. M. MOUSA
}

\author{
Department of Biochemistry, Faculty of Veterinary Science, \\ P. O. Box 32, Khartoum North, Sudan
}

Received November 6, 1992

\begin{abstract}
Mou s H. M.: Ruminal and blood characteristics of Nubian goats dosed with the growth promoter monensin. Acta vet. Brno, 63, 1994: 13-17.

Twelve cannulated male growing bucks (goats) were used in a 56-day study to determine the effect of monensin on ruminal and blood characteristics on animals receiving $10 \mathrm{mg}$ of monensin solution daily through the rumen cannula.

There was slight increase in body weights of treated animals. Monensin increased significantly $(P<0.001)$ the level of blood glucose and decreased $(P<0.001)$ the concentration of plasma lactic acid, urea and magnesium. Serum albumin, cholesterol, sodium, chloride, potassium and calcium were not affected after treatment.

In the rumen fluid, there was a significant decrease in rumen ammonia $(\mathrm{P}<0.001)$, the molar proportion of acetic acid $(\mathrm{P}<0.001)$ and acetate: propionate ratio $(\mathrm{P}<0.05)$. A significant increase $(\mathrm{P}<0.001)$ in the level of propionic acid was detected. Other volatile fatty acids and the $\mathrm{pH}$ of the rumen were not affected.
\end{abstract}

\section{Monensin, growth promoter, Nubian goats, biochemical parameters}

Monensin is a biologically active compound produced by the fungus Streptomyces cinamonensis. It is a carboxylic polyether ionophore. It is classified as an ionophore because it facilitates transport of monovalent cations across membranes (Pressman 1976).

Monensin was found to alter rumen fermentation and increase the efficiency of feed utilization by growing and finishing cattle (Potter et al. 1976; Boling et al. 1977; Dinius and Baile 1977). The change in the fermentation pattern is brought about by the fact that monensin changes the rumen ecology. It enhances the growth of some microorganisms and inhibits the growth of others, this in turn changes the concentration of the products of fermentation towards a more beneficial effect to the host.

Although monensin is extensively used in Europe and the United States, as a feed additive, it has not been introduced in this country before.

As part of an extensive study in the use of monensin as growth promotor for local breeds of ruminants in this country, the present work aims at investigating the basic biochemical changes, reported as associated with monensin in cattle, in young growing goats in the Sudan.

Animals and feed

\section{Materials and Methods}

Twelve healthy Nubian bucks (Capra hircus), aged 5-7 months and weighing 10-15 kg, were fitted with rumen cannulae and housed in separate pens. Throughout the experimental period, the animals were fed on mature dry Abu-70 forage (Sorghum vulgaris, var.). Samples of Abu-70 analysed for chemical composition according to the A. O. A. C. (1970) contained (on DM basis) $5.2 \% \mathrm{CP}(0.83 \% \mathrm{~N}), 1.8 \% \mathrm{EE}, 25 \% \mathrm{CF}$ and $8.1 \%$ ash. Water and food were available ad libitium.

\section{Experimental procedure}

The animals were kept for two weeks of adaptation period before the start of the experiment. The experiment began by dividing the animals into two groups, six each, group $\mathbf{C}$ (control) and group $\mathbf{M}$ (treated with monensin).

The sodium salt of monensin (crystalline potency $885 \mathrm{mg} / \mathrm{kg}$ ), obtained from Lilly Research Centre, England), was suspended in water and each animal in group $M$ received an equivalent of $10 \mathrm{mg}$ monensin daily through the rumen cannula for 56 days. At the end of the treatment period, blood $(10 \mathrm{ml})$ was collected into heparinized tubes. Plasma was collected by centrifugation of the blood at $900 \mathrm{~g}$ for 10 minutes, then stored at $-20^{\circ} \mathrm{C}$, pending analysis. Another blood sample was collected from the opposite jugular vein for serum preparation.

Rumen fluid was obtained by a syringe fitted with a rubber tubing and inserted through the cannula. Rumen fluid ( $5 \mathrm{ml}$ ) was sucked from each animal and transferred to small vials, containing $0.5 \mathrm{ml}$ formic acid as preservative, for determination of volatile fatly acids (VFA). Another rumen sample was collected for the other determinations. Body weights were recorded at the start and at the end of the experimental period. Food intake was also observed. 
Biochemical analysis

Blood glucose was determined by the method of Hy varine n and Nikkila (1962). Plasma urea and serum albumin were determined by the methods of Evan s (1968) and B artholome w and Delaney (1966), respectively. The enzymatic-colorimetric method of All a in et al. (1974) was used for the determination of cholesterol. Lactic acid in plasma was determined by the method of B arker and S u m me r s on (1941), while $\beta$-hydroxybutyrate was estimated according to Will a m s on and Mell a n by (1974). Serum Ca, Mg, K and Na were determined by atomic absorption spectroscopy. Chloride concentration in serum was determined by chloride meter (Corning EEL-920-Chloride meter).

In the ruminal fluid, VFA were determined by gas liquid chromatography. Ammonia was assayed by the phenolhypochlorite method ( $\mathrm{Ch}$ an ey and $\mathrm{Marbach} \mathrm{1962)} \mathrm{and} \mathrm{pH}$ was determined using a Digital Jurgens pH 90 Ingold pH-meter.

\section{Statistical methods}

The reported values are means \pm SD. Comparisons between the means were conducted using Student's $t$ test. $P$ higher than 0.05 was considered non-significant.

\section{Results}

It is evident from Table 1 that administration of monensin resulted in a significant increase $(P<0.001)$ in the level of glucose, while there was a significant decrease $(P<0.001)$ in the level of plasma urea and plasma lactic acid. Albumin, cholesterol and $\beta$-hydroxybutyrate concentrations were not affected by the treatment.

Table 1

Concentration of selected metabolites and elements in the blood of normal and monensin treated goats

\begin{tabular}{|lcc|}
\hline Parameter & Control & Treated \\
\hline Glucose $(\mathrm{mg} / \mathrm{dl})^{* *}$ & $42.3 \pm 1.2^{\mathrm{a}}$ & $54.4 \pm 2.2^{\mathrm{b}}$ \\
Urea $(\mathrm{mg} / \mathrm{dl})^{* *}$ & $17.4 \pm 0.8^{\mathrm{a}}$ & $1.3 \pm 1.1^{\mathrm{b}}$ \\
Cholesterol (mg/dl) & $79.0 \pm 2.4$ & $81.0 \pm 1.6$ \\
Lactic acid (mg/dl)** & $14.2 \pm 0.6^{\mathrm{a}}$ & $8.5 \pm 1.4^{\mathrm{b}}$ \\
Albumin (g/d) & $3.4 \pm 0.4$ & $3.2 \pm 0.3$ \\
$\beta$-hydroxybutyrate (mmol/L) & $0.65 \pm 0.02$ & $0.62 \pm 0.3$ \\
$\mathrm{Na}(\mathrm{mmol} / \mathrm{L})$ & $147.2 \pm 1.8$ & $152.0 \pm 1.4$ \\
Cl (mmol/L) & $102.0 \pm 3.0$ & $103.3 \pm 2.7$ \\
$\mathrm{~K}(\mathrm{mmol} / \mathrm{L})$ & $2.86 \pm 0.2$ & $2.9 \pm 0.3$ \\
$\mathrm{Mg}(\mathrm{mmol} / \mathrm{L})^{*}$ & $0.83 \pm 0.03^{\mathrm{a}}$ & $0.52 \pm 0.02^{\mathrm{b}}$ \\
\hline
\end{tabular}

Means on the same line having different superscripts are significantly different at: $\quad * \mathrm{P}<0.05$

$* * P<0.001$

As for serum electrolytes, there was a significant decrease $(\mathrm{P}<0.05)$ in the concentration of $\mathrm{Mg}$ in animals treated with monensin and a slight non-significant increase in the $\mathrm{Na}$ level. Other electrolytes, $\mathrm{Cl}, \mathrm{K}$ and $\mathrm{Ca}$ seemed to be unaffected by the treatment.

Results of the parameters investigated in ruminal fluid are presented in Table 2.

Table 2

Effect of monensin on rumen volatile fatty acids concentration, $\mathrm{pH}$ and $\mathrm{NH}_{3}$

\begin{tabular}{|lcc|}
\hline Parameter & Control & Treated \\
\hline $\mathrm{pH}$ & $6.5 \pm 0.3$ & $6.3 \pm 0.1$ \\
$\mathrm{NH}_{3}(\mathrm{mg} / \mathrm{dl})^{* *}$ & $26.0 \pm 2.7^{\mathrm{a}}$ & $17.3 \pm 1.5^{\mathrm{b}}$ \\
Total VFA (mmol/) & $77.8 \pm 2.4$ & $75.2 \pm 2.6$ \\
Acetic** $_{\text {Propionic** }}^{* *}$ & $63.4 \pm 1.3^{\mathrm{b}}$ \\
Butyric $^{+}$ & $66.7 \pm 1.2^{\mathrm{a}}$ & $23.5 \pm 0.7^{\mathrm{b}}$ \\
Iso-butyric $^{+}$ & $20.1 \pm 0.8^{\mathrm{a}}$ & $9.4 \pm 0.2$ \\
Valeric $^{+}$ & $9.2 \pm 0.1$ & $0.7 \pm 0.3$ \\
Iso-valeric $^{+}$ & $0.8 \pm 0.2$ & $1.1 \pm 0.6$ \\
Acetate: Propionate ratio* & $1.3 \pm 0.5$ & $2.7 \pm 0.2$ \\
\hline
\end{tabular}

Means on the same line having different superscripts are significantly different at: $* P<0.05$

** $\mathrm{P}<0.001$

+ Molar proportions of individual fatty acid expressed as per cent of total VFA concentration 
There were no significant changes in the rumen fluid $\mathrm{pH}$ and total VFA molar concentration between the two groups. However, there was a significant decrease $(\mathrm{P}<0.001)$ in the level of rumen $\mathrm{NH}_{3}$ in treated animals.

The acetic acid concentration, when calculated as percentage of the total VFA, was significantly reduced $(\mathrm{P}<0.05)$ by the treatment while the percentage of propionic acid was significantly increased $(\mathrm{P}<0.05)$ and consequently there was a significant decrease in the acetate: propionate ratio. Other VFA (butyric, iso-butyric, valeric and iso-valeric) were not affected by monensin treatment.

The body weights at the start of the experiment were $14.5 \pm 1.2 \mathrm{~kg}$ for the control animals and $14.7 \pm 1.6 \mathrm{~kg}$ for the group to be treated with monensin. At the end of the experiment, the average body weight of the controls was $16.4 \pm 0.8 \mathrm{~kg}$ and that of the treated group was $17.6 \pm 1.2 \mathrm{~kg}$. Although there was an increase in body weight of the treated animals, the increase was found non-significant. It is worth mentioning that animals treated with monensin were observed to be slightly anorexic, as was judged from the food residue collected each morning.

\section{Discussion}

A long cherished dream of nutritionists has been to manipulate and improve the efficiency of ruminal fermentation. This has meant to increase ruminal propionic acid yield, depress ruminal deamination of amino acids and methanogenesis.

In this study, the level of rumen $\mathrm{NH}_{3}$, and consequently plasma urea, was found to be significantly reduced. This implies that deamination of amino acids by rumen microbes was also reduced. The amino acids instead of being degraded for energy purposes will pass through the digestive tract to be absorbed by the intestine and ultimately used by the animal for building its own proteins. Similar results were reported by Nockels et al. (1978), Ow en s et al. (1978) and S chelling (1984) in cattle. One of the reasons reported to explain this is the fact that monensin causes $66 \%$ decrease in ruminal urease activity ( S t a r n er et al. 1984).

Monensin treatment in this experiment increased the blood glucose level. Presumably this is related to the increase in the molar proportion of propionate, which is the main precursor of glucose in ruminants, by gluconeogenesis (Con $n$ and $S t u m p f$ 1987). Propionate was increased at the expense of acetate without affecting the total VFA production. This is in agreement with the finding of Richard s on et al. (1976) in cattle.

The increase in rumen propionate will have a sparing effect on glucogenic amino acids. Instead of being degraded for energy purposes, they will be used for the repair and building of animal tissues because the increase in glucose will satisfy the energy requirements of the animals.

From the foregoing considerations, one should expect that monensin would cause a significant increase in the body weights of animals. This did not take place in this experiment possibly because treated animals were slightly anorexic. Similar findings were reported by Bergen and Bates (1984). However, the anorexia noticed in treated animals was not severe enough to cause starvation because the level of $\beta$-hydroxybutyrate was lower than $0.7 \mathrm{mmol} / 1$. Plasma $\beta$-hydroxybutyrate concentration has been used as an index of nutritional status in sheep, with a value of $0.7 \mathrm{mmol} / \mathrm{l}$ indicating undernutrition ( $\mathrm{R} \mathrm{u}$ s s el et al. 1977). This, taken together with serum albumin concentrations which were similar in the control and monensin treated animals, indicates that these animals are not utilizing their body reserves because serum albumin concentrations are related to changes in body protein contents (Sykes and Thompson 1979).

Monensin has been shown to have affinities for a number of cations including $\mathrm{K}, \mathrm{Na}, \mathrm{Ca}$ and $\mathrm{Mg}$ (Press man 1976). In this study, with the exception of $\mathrm{Mg}$, there was no signifi- 
cant change in the concentration of these cations in the sera of treated goats. The lowering in the level of $\mathrm{Mg}$ indicates high affinity of monensin and its ability to carry this cation across the lipid bilayer compared with other cations.

A further advantage of monensin is that it lowers the level of lactic acid (Table 1); this will prevent lactic acidosis in animals when engorged with grains and will also maintain ruminal $\mathrm{pH}$. De $\mathrm{n} n$ is et al. (1981) reported that monensin inhibits the growth of ruminal lactate producers without inhibiting lactate utilizers.

It can be concluded that monensin can be used successfuly as a growth promoter in goats provided that further studies are made on the appropriate dose and its relation to the quality of food available to these animals. Other growth promoters like anabolic implants (Zeranol, progesterone-estradiol or testosterone-estradiol) are expensive and less convenient for use in goats.

\section{Acknowledgement}

The author would like to thank the Government of Lower Saxony, Germany, for sponsoring part of this study and for giving the author the chance to do some of the analysis in the Laboratories of the Faculty of Veterinary Medicine, Hannover. Thanks are also extended to Professor S. E. I. Adam for revising the manuscript.

\section{Metabolický profil bachorové tekutiny a krve u nubijských koz po podání monensinu}

Účinek monensinu na některé biochemické parametry krve a bachorové tekutiny byl sledován u mláđat nubijských koz po dobu 56 dní. Kủzlata dostávala denně v roztoku $10 \mathrm{mg}$ monensinu pomocí žaludeční kanily. U pokusných zvířat byl zjištěn mírný vzrůst tělesné hmotnosti. Signifikantní zvýŠení $(\mathrm{P}<0.001)$ bylo zjištěno v hladinách krevní glukózy; signifikantní snížení $(\mathrm{P}<0.001)$ bylo zaznamenáno v koncentracích kyseliny mléčné, močoviny a hơ̌č́ku v plazmě. Podávání monensinu neovlivnilo sérové hladiny albuminu, cholesterolu, sodíku, chloridů, draslíku a vápníku. $\mathrm{V}$ bachorové tekutině byl zjištěn výrazný pokles $v$ koncentraci amoniaku $(\mathrm{P}<0.001)$, v molárním podílu kyseliny octové $(\mathrm{P}<0.001)$ a v poměru acetátu $\mathrm{k}$ propionátu $(\mathrm{P}<0.05)$. Byl detekován signifikantní vzrůst hladiny kyseliny propionové $(\mathrm{P}<0.001)$. Další těkavé mastné kyseliny a pH bachoru nebylo ovlivněno.

\section{Мөтаболичөский профиль рубцовой жидкости и крови нубийских коз после дачи монензина}

Проводили исследования воздействия монензина на некоторые биохимические параметры крови и жидкости рубца козлят в течение 56 суток. Козлятам давали 10 мг монензина в растворе в сутки с помощью желудочной канюли.

На подопытных животных установили незначительное увеличение массы тела. Существенное увеличение $(P<0.001)$ выявили в уровнях глюкозы крови; существенное понижение $(P<0.001)$ - в концентрации молочной кислоты, мочевины и магния в плазме.

Дача монензина не оказала влияние на сывороточный уровень альбумина, холестерина, натрия, хлоридов, калия у кальция.

В жидкости рубца было установлено выразительное понижение в концентрации аммиака $(P<0.001)$ в молярной доле кислоты.

\section{References}

ALLAIN, C. C.-POON, L. S.-CHAN, C. S. G.-RICHMOND, W.-FU, P. C.: Enzymatic-colorimetric method for cholesterol determination. Clin. Chem., 20, 1974: 270. 
A. O. A. C.: Official Methods of Analysis (11th ed.) Association of Official Agricultural Chemists. Washington, D. C., 1970.

BARKER, S. B.-SUMMERSON, W. H.: Preparation and colorimetric determination of lactic acid. J. Biol. Chem., 138, 1941: 535 .

BARTHOLOMEW, R. J.-DELANEY, A. M.: Aust. Ass. Clin. Biochem., 1, 1966: 214.

BERGEN, W. G.-BATES, D. B.: Ionophores: Their effect on production efficiency and mode of action. J. Anim. Sci., 58, 1984: 1465-1483.

BOLING, J. A.-BRADLEY, W.-CAMPBELL, L. D.: Monensin levels for growing and finishing steers. J. Anim. Sci., 44, 1977: 867.

CHANEY, A. L.-MARBACH, E. P.: Modified reagents for determination of urea and ammonia. Clin. Chem., 8, 1962: 130.

CONN, E. E.-STUMPF, P. K.: Outline of Biochemistry, 5th edition. John Wiley and Sons, New York 1987, p. 693.

DENNIS, S. M.-NAGARAJA, O. M.-BARTLEY, E. E.: Effect of lasalocid or monensin on lactate producing or using rumen bacteria. J. Anim. Sci., 52, 1981: 418.

DINIUS, D. A.-BAILE, C. A.: Beef cattle response to a feed intake stimulant given alone and in combination with propionate enhancer and an anabolic agent. J. Anim. Sci., 45, 1977: 147.

EVANS, R. T.: Manual and automated method for measuring urea based on modification of its reaction with diacetyl monoxime and thiosemicarbazide. J. Clin. Path., 1, 1968: 527-529.

HYVARINEN, A.-NIKKILA, E. A.: Specific determination of blood glucose with o-toluidine. Clin. Chem., 7, 1962: 140-143.

NOCKELS, C. F.-JACKSON, D. W.-BERRY, B. W.: Optimum level of monensin for fattening lambs. J. Anim. Sci., 47, 1978: 788-790.

OWENS, F. M.-SHOCKEY, B. J.-FENT, R. W.-RUST, S. R.: Monensin and abomasal protein passage of steers. J. Anim. Sci., 47 (Supplement), 1978: 114.

POTTER, E. L.-VAN DUYN, R. L.-COOLEY, C. O.: Monensin toxicity in cattle. J. Anim. Sci., 58, 1984: 1499-1511.

PRESSMAN, B. C.: Biological application of ionophores. Ann. Rev. Biochem., 45, 1976: 501.

RICHARDSON, L. F.-RAUN, A. P.-POTTER, E. L.-COLLEY, C. O.-RATHMACHER, R.P.: Effect of monensin on rumen fermentation in vitro and in vivo. J. Anim. Sci., 43, 1976: 657.

RUSSEL, A. J. F.-MAXWELL, T. J.-SIBBALD, A. R.-McDONALD, D.: J. Agr. Sci. Camb., 89, 1977: 667.

SCHELLING, G. T.: Monensin mode of action in the rumen. J. Anim. Sci., 58, 1984: 1518-1527.

STARNER, S. R.-SPEARS, J. W.-FROETSCHEL, M. A.-CROOM, Jr.: Influence of monensin and lasalocid on mineral metabolism and ruminal urea activity in steers. J. Nutr., 114, 1984: 518.

WILLIAMSON, D. H.-MELLANBY, J.: In: Methods of Enzymatic Analysis. Ed. H. U. Bergmeyer. Vol. 4, London and New York 1974. 